Nationalism Studies between Methodological Nationalism and Orientalism: An Alternative Approach Illustrated with the Case of El Greco in Toledo, Spain

\author{
Eric Storm \\ Institute for History \\ Leiden University
}

Post-print

Original published in:

Nations and Nationalism 21 (4), 2015, 786-804.

http://onlinelibrary.wiley.com/doi/10.1111/nana.12111/abstract

DOI: $10.1111 /$ nana.12111 
Nationalism Studies between Methodological Nationalism and Orientalism: An Alternative Approach Illustrated with the Case of Toledo, Spain ${ }^{1}$

Since the 1980s the field of nationalism studies has changed profoundly. An immense amount of publications has contributed to improving our understanding of the rise of nationalism and the subsequent construction and diffusion of national identities in various parts of Europe and around the world. During the last few decades the field has also been broadened substantially and now also deals with the role of gender, with the impact of nationalism on popular culture, and with similar processes of collective identity construction on an imperial, regional and local level, which generally are closely related to the nation-building process that was going on at the same time. Nevertheless, the overwhelming majority of recent scholarship consists of case studies that focus on a specific local, regional, national or imperial topic, while taking one state or national movement as their frame of reference. This way, in fact, the history of nationalism is still presented as a collection of isolated national cases.

Admittedly, theoretical studies often adopt a global framework, but this mostly results in a rather abstract approach. In general, they cannot take into account the detailed results of most case studies. Historical overviews of the rise and development of nationalism in a broad area that attempt to integrate at least some of these findings are still very rare (Thiesse 1999; Leerssen 2006a). More problematic is the lack of comparative studies based on original research in primary sources. Since Umut Özkirimli (2000: 233) in his Theories of Nationalism argued that there is an urgent need for 'theoretically informed comparative histories', not much has changed (Leerssen 2006b; Núñez 2010). Apart from the seminal books by Hroch (1985) and Greenfeld (1992), there are only a few edited volumes (e.g. Baycroft and Hewitson 2006; Augusteijn and Storm 2012; Van Ginderachter and Beyen 2012) that try to provide a comparative perspective - although almost all chapters still deal with single national cases - and a small number of studies in which a few countries or regions are compared (Jeismann 1992; Tacke 1995; Storm 2010; Murdock 2010).

Although the lack of comparative studies is a serious problem, maybe even more critical is the implicit methodological nationalism that can be found in most studies on nationalism. The term methodological nationalism was introduced by Wimmer and Glick Schiller (2002) to criticise the unreflective use of national units in the discipline of sociology. Today, most investigators in the field of nationalism studies will not uncritically see nations as a natural given, nor will they gloss over nationalism as irrelevant and something that we have left behind us. Nevertheless, many still adhere to a third variety of methodological nationalism: 'the reduction of the analytical focus to the boundaries of the nation state' (2002: 225). Thus, studies of nationalism in the Western world generally limit the scope of their investigation to one national context, while ignoring external actors and outside influences. Consequently, the various stages in the rise of nationalism or in the nation-building process are analysed along national lines and historical events that particularly affected the nation being studied - such as revolutions or wars - function as the main turning points. Moreover, nationalism studies generally are firmly embedded within a specific national historiographical debate. As Charlotte Tacke (1998) has pointed out for Germany and France, this implies that in the former the focus has been primarily on expressions of cultural nationalism, while in the latter case most scholars have studied topics related to political nationalism (also Hewitson 2006). This methodological nationalism is even invigorated by the use of concepts that are intimately connected with one national case, such as the Risorgimento in Italy, Heimat in Germany, jacobinisme or laïcité in France, 'Home Rule' in the case of the United Kingdom and 'manifest destiny' or the idea of the 'frontier' in the United States. In fact, one can conclude that the field of nationalism studies has not yet completely cast off the shackles of the nationalist interpretation of the past. 
Currently, many scholars are aware that a more transnational approach is needed and recently there is more attention for international transfers. Already in 1999, the French expert in nationalism studies Anne-Marie Thiesse (1999: 11) began her book on the creation of national identities in Europe with the conclusion: 'There is nothing more international than the formation of national identities'. She then adds that these collective identities derive 'from the same model, while the adjustment is accomplished within the framework of intense international interchanges'. Similar attempts to develop a transnational model by mapping developments in a large number of European countries, while paying explicit attention to international transfers, have been carried out by Joep Leerssen, who focuses on nineteenthcentury cultural nationalism in Europe (2006b and spinnet.eu), and by Stefan Berger's project Representations of the Past: The Writing of National Histories in Nineteenth and Twentieth Century Europe (e.g. Berger and Lorenz 2010). Nevertheless, even in this type of study only members of the proper nation are given agency, while foreigners - apart from a very limited number of exceptions who took an active part in another national movement - function as an opponent, or at most as an external source of inspiration.

This exclusive attention for the national sphere when studying a specific national movement or nation-building process is even more remarkable when we realise that the way the collective identities from Western countries were perceived and shaped from abroad has already been widely investigated within another disciplinary tradition: imagology. In a great number of studies, the images of foreign countries and regions created by travellers, writers, scholars and artists have been the object of detailed analysis (e.g. Leerssen and Beller 2007; Zacharasiewicz 2010). Nonetheless, almost all scholars within this disciplinary tradition concentrate on the production side and do not investigate the impact of these foreign images on the host societies.

Curiously, similar studies on non-Western areas have a very different approach. In general their authors recognize that when power-relations between observers and the observed are unequal, the gaze of the outsider can be intimidating and can significantly influence the self-perception of the observed. In Edward Said's ground-breaking Orientalism (1978), the active role of the native population is even minimized. According to him, the identity of the Middle East has been imposed on it by the West, and especially by supposedly objective Western scientists. Inspired by Said, the analysis of this process of 'othering' has been a major topic in post-colonial studies. In a similar way, nationalism in Asian or African countries has been regarded as a Western import or as a 'derivative discourse' (Chatterjee 1993) and those who examine the still ongoing process of the construction of modern 'imagined communities' often focus on the role of outsiders, such as foreign tourists. Thus, in a fascinating study, Adrian Vickers (1989) showed how foreign residents and visitors shaped the image of the Indonesian island of Bali as an exotic paradise.

Thus, while in studies on nationalism and nation-building in Western countries foreigners are only passive onlookers or at most provide sources of inspiration; in investigations on non-Western areas it seems that outsiders almost entirely determine the collective identity of the local population. In the former, methodological nationalism is dominant, while in the latter 'orientalism' is still seen as an omnipresent shaping force. Nonetheless, many specialists of the process of collective identity construction in the nonWestern world are beginning to pay more attention to the interaction between inhabitants and foreigners, as is the case, for example, with those who focus on the impact of international tourism on communities in Latin America, Asia and Africa (Smith and Brent 2001; Chambers 2010), while those who study nationalism in the Third World concentrate more on the active role of local actors in adapting foreign ideas and models to their own national context (Bayly 1998; Manela 2009). In this article, I will propose a more nuanced approach for the Western world as well. By focusing on Spain, and more particularly on the role of the city of Toledo in 
the Spanish national imagination during the nineteenth and early twentieth century, I will challenge the dominant methodological nationalism in nationalism studies and propose a more encompassing way to analyse the construction of national identities in Europe by also including the role of foreign actors.

\section{The case of Spain and Toledo}

Spain constitutes an interesting case. Although Spain is often seen as a peripheral country, the study of Spanish nationalism and outside perceptions neatly fits within the Western pattern. As a result, those who study Spanish nationalism only focus on domestic actors, while the view from outside is generally ignored (Mar-Molinero and Smith 1996; Moreno Luzón 2007; Álvarez Junco 2011) or discussed separately (Morales Moya, Fusi Aizpurúa and Blas Guerrero 2013: 1031-1203). The historiography on Spanish nationalism also largely adheres to the methodological nationalism that can be detected in the rest of the Western world. Thus, the so-called War of Independence of 1808-1814 (the name itself is clearly a product of a nationalist interpretation of the past) is generally seen as a starting point for Spanish nationalism, while the humiliating defeat in the Spanish-American War of 1898, the Spanish Civil War (1936-1939) and the transición (the transition to democracy after the death of Franco in 1975) are seen as the major turning points. Moreover, the focus in Spanish historiographical debates has overwhelmingly been on the rise of peripheral nationalisms in Catalonia, the Basque Country and Galicia and the related issue of the supposed weakness of Spanish nationalism (Archilés 2009; Molina and Cabo Villaverde 2012), while widely used Spanish concepts such as regeneracionismo (a nationalist motivated movement that pleaded for more state intervention after 1898), castizo (purely Spanish) and nacionalcatolicismo (national-Catholicism, the right-wing nationalist ideology of the Franco-regime) also suggest that the Spanish case is fundamentally different from others.

Although after the seventeenth century Spain slowly lost its central role in international affairs, the country exerted a strong attraction on foreign travellers. Partly building upon the earlier tradition of the Black Legend - a view that was particularly strong in protestant countries like the Netherlands and Great Britain and that portrayed the country and its kings as the embodiment of cruelty, repression, intolerance and superstition - travellers, authors, painters and playwrights from the rest of Europe (and the United States) often portrayed it as a backward and barbaric country, but also as a fascinating and exotic destination. Those who examine this view from abroad sometimes even argue that Spain and particularly Andalusia with its Moorish remains, colourful traditions and passionate inhabitants - was 'orientalised' like so many non-Western areas. Nonetheless, like other practitioners in the field of imagology in a Western context, they only analyse the production of these images and generally ignore their impact on the self-perception of the inhabitants (e.g. Torrecilla 2004; Boone 2007; Méndez Rodríguez, Plaza Orellana and Zoido Naranjo 2010).

Within Spain, the focus will be on Toledo. With its important role in Spanish history especially until 1561, when Philipp II transferred the court from Toledo to Madrid - and its impressive and multifarious historical patrimony, Toledo attracted a growing number of (foreign) visitors, while also becoming an indispensable part of the Spanish national heritage and memory. It therefore constitutes an ideal case to examine the interaction between the view from abroad and the local construction of a collective identity and make clear that the place of Toledo within the Spanish national imagination was largely determined by foreigners. This could be demonstrated by focusing on foreign visitors, which from about the beginning of the nineteenth century were particularly interested in Toledo for its exotic Moorish and Jewish remains. Spanish travellers and intellectual elites slowly assimilated this interest in those 
aspects of the city's heritage that were seen as unique by foreigners (Martínez Gil 2007: 15791). However, the local Committee of Historical and Artistic Monuments, that since 1844 supervised the provincial cultural heritage, was primarily interested in the Christian monuments from the period of the Visigoths, the gothic era and the Spanish Golden Age (García Martín 2010: 510-11). It took much longer for the local population to assimilate the fascination with the more exotic aspects of its past. Still in 1913, a local Catholic newspaper was in favour of demolishing part of the old Jewish quarter in order to modernize the city and construct new and more hygienic houses (El Castellano, 20 September 1913).

The impact of foreign observers, however, becomes even more apparent when focusing on Toledo's artistic heritage, and particularly the works of the painter that stands out among all: Domenikos Theotokopoulos, better known as El Greco. Although Domenikos was born and raised on Crete and received his artistic training in Venice, he produced most of his major works in Toledo, where he arrived around 1576 when he was about 35 years of age. After his death in 1614, nonetheless, he rapidly slid into oblivion. Interestingly, his oeuvre was rediscovered during the nineteenth century and he came to be seen as a quintessentially Spanish painter who stood at the cradle of the country's Golden Age. I will now examine this process respectively on an international, national and local level.

\section{The rediscovery of El Greco}

The rediscovery of El Greco was made possible by the rise of Romanticism, which caused a profound transnational transformation of cultural taste and, as a consequence, a broad revaluation of Europe's artistic past. Instead of works of art that conformed to the international canon based on Classical Antiquity and the Italian Renaissance, Romantic intellectuals and artists preferred individual creativity and national authenticity. Thus, those painters that did not conform to the classicist ideals, such as Van Eyck in Flanders, Rembrandt in the Netherlands and Grünewald in Germany, were now preferred to those who merely imitated the great masters of the Italian Renaissance. This also paved the way for El Greco, who in the seventeenth and eighteenth century was almost unknown outside of Spain, while Spanish connoisseurs saw him as a foreigner and as a capable but rather eccentric painter.

El Greco was not only appreciated in a new way, he also was converted into a Spanish artist. Strikingly, this process was initiated outside of Spain. The first step was set in France, where King Louis Philippe decided to profit from the First Carlist War of 1833-1839, a civil war in neighbouring Spain. The Spanish government's decision to expropriate a large proportion of the property of the Church, in order to finance the war effort, flooded the art market with high quality pieces. In 1837, the French King sent a few specialists who succeeded in acquiring about 500 masterpieces and smuggling them out of Spain. The next year, the paintings were shown in a newly arranged Galerie Espagnole in the Louvre. The collection also contained nine works of El Greco. Romantic authors and artists, such as Théophile Gautier and Eugène Delacroix were fascinated by the originality of El Greco's painting style. The Lady in a Fur Wrap, which was thought to represent El Greco's daughter, even caused a sensation and was compared with Da Vinci's Mona Lisa. Although some of his more extravagant paintings were considered awkward, everybody accepted El Greco as part of this collection of Spanish art (García Felguera 1991; Baticle and Marinas 1981; Luxenberg 2008).

Although one could argue that El Greco's inclusion in the Spanish Gallery, which was dissolved after 1848, had not been premeditated, this would be different in the case of scholars writing on the history of Spanish art. An important component of the Romantic programme was the nationalistic reinterpretation of history and thus also the artistic past had 
to be rewritten along national lines. Again the first nationalist reinterpretation of the Spanish artistic past was published by a foreigner, the British author William Stirling, a young Cambridge-educated historian. In the three volumes of Annals of the Artists of Spain (1848), he analysed the development of Spanish art through the ages. Contrary to earlier encyclopaedic works, such as Antonio Ponz's eighteen volumes Viaje de España (1772-94) or the six volumes of Juan Augustín Céan Bermúdez's Diccionario histórico de los más ilustres profesores de las Bellas Artes en España (1800), he did not order his narrative alphabetically or geographically, while implicitly measuring the art works against an absolute standard of beauty, but by chronology. This historicist approach meant that he tried to show how art and its ideals of beauty developed over time and were influenced by specific - and hence national - historical circumstances. Like his predecessors, Stirling still discussed the works of foreign artists that were present in Spain, but he paid more attention to those Spanish artists that considerably contributed to the nation's idiosyncratic artistic evolution. Stirling appreciated Spanish painting for its realism and for taking nature - not the classics - as its model. By doing so, he described Spanish art in terms of a clearly distinguishable trend that was the product of the nation's history and particular disposition. Since he understood and appreciated El Greco's early work as being highly realist, he awarded him an honourable place in the rise of a truly Spanish School that culminated in the art of the great seventeenth-century court painter Diego Velázquez (Stirling-Maxwell 1891: I, 328-44).

The next step in historicising the Spanish artistic past - and implicitly also its nationalisation - was taken in France. In 1861 Charles Blanc began publishing the 14 volumes of his Histoire des peintres de toutes les écoles. In the volume on Spain, which appeared in 1869, only Spanish artists were discussed, including El Greco, thus further solidifying the naturalization of his art as Spanish. Blanc identified a preference for drama, a deeply felt religiosity, and a proud sentiment of reality as being characteristic for Spanish art (Blanc 1869: 19). In the book, which was popular among artists because of its many beautiful illustrations, El Greco was presented as an independent spirit, who after his arrival in Spain shed the vestiges of his Venetian artistic education. This way he became the harbinger of a new, more truly Spanish school (Lefort 1869).

The same mixture of realism, historicism and nationalism could also be found in the writings of the German art historian Carl Justi. Even more than Stirling and Blanc he connected the story of Spanish art with the historical evolution of Spanish society, in this case that of the seventeenth century. In the two volumes of his Diego Velazquez und sein Jahrhundert (1888), which contained a wide panorama of artistic developments during Spain's Golden Age, he presented Velázquez as the most characteristic painter of the 'naturalistic' Spanish School. At the same time, the author considered El Greco as one of his most important precursors. While Lefort still referred to an old legend that stated that El Greco changed his style shortly after his arrival in Toledo in order not to be seen as an imitator of Titian, Justi did not interpret this as the result of an individual decision, but of the impact of his new environment. It was because of his contact with the realistic Spanish popular spirit that El Greco succeeded in liberating himself from the spell of Italian idealism. In an altar piece like the Assumption of the Virgin, one of his first commissions in Toledo, he painted apostles who seemed to originate directly from Toledo's surrounding countryside (Justi 1888: I, 4-11, 76-80 and 118). A few years later, in two articles dedicated exclusively to El Greco, he explained that Toledo had been a perfect place for El Greco to get acquainted with the Spanish Volksgeist. Situated on a granite rock surrounded by the river Tagus, with its long history dating back to Roman times and with its Moorish, Jewish and Christian monuments, it formed a kind of recapitulation of Spain's rich past and harsh environment. Justi therefore argued that El Greco's palette lost its 'Venetian wealth of colours in the rough and dry atmosphere of this Castilian hill'. At the same time he perfectly managed to capture 
the 'Spanish character of the times of Philipp II' in his paintings (Justi 1908: 222-24).Thus, according to Justi, El Greco rapidly adapted himself to his new environment and therefore had a leading role in reorienting Spanish art back to its native roots.

In the meantime, Spanish historians and art critics also published a growing number of case studies on particular artists, works or groups of painters, which more or less conformed to the nationalist reinterpretation of Spain's artistic past as given by Stirling, Blanc and Justi (Portús 2012). ${ }^{2}$ They did not slavishly copy the interpretation of their British, French or German colleagues, but since the first overview of Spanish art written by a Spanish author Manuel Bartolomé's Cossío's 'Aproximación a la pintura española' which appeared in episodes in the Boletín de la Institución Libre de Enseñanza - was only published in 1886, they only produced fragments of the entire story. Thus, a new, nationalist reinterpretation of the Spanish artistic past was primarily the work of foreign art historians, or at most the result of a collaborative effort of both foreign and domestic authors. The role of foreign authors was even more crucial in the transformation of the largely forgotten Theotokopoulos into a Spanish painter and one of the main precursors of the Spanish Golden Age (Álvarez Lopera 1987; Storm 2011).

The appreciation of El Greco's peculiar painting style followed a similar pattern. From about 1860, innovative foreign artists began to appreciate El Greco's technique. His works could function as a source of inspiration to break away from the 'artificial' and 'insipid' academic style that had become dominant during the nineteenth century. Delacroix and Millet had already acquired some small paintings of El Greco, but his breakthrough as a first rank painter was brought about by impressionists like Manet, Degas and Cézanne (Álvarez Lopera 1987: 53-62; Storm 2011: 37-47). In the twentieth century, he became even more closely connected to the avant-garde by the extremely influential German art critic Julius MeierGraefe (1910), whose exalted praise of the modern painterly qualities of El Greco's oeuvre caused a true Greco-mania among expressionist painters in Central Europe (Schroeder 1996; Storm 2008; Wismer and Scholz-Hänsel 2012). Even Santiago Rusiñol and Ignacio Zuloaga, two Spanish painters who played an important role in spreading his fame as one of the world's greatest artists, got infected with the Greco virus in Paris, at a moment - in 1894 when they were just beginning their artistic careers. (Fontbona 1996; Storm 2011: 75-102). ${ }^{3}$

\section{A national hero}

When in 1908 the Spanish scholar Manuel Bartolomé Cossío portrayed El Greco's oeuvre as one of the greatest highlights of the Spanish artistic heritage, he merely confirmed the interpretations and judgments that had been formulated during the preceding sixty years by foreign authors and artists. In his extensive biography of the Toledan painter, which also contained a first and quite complete catalogue of El Greco's oeuvre, Cossío described him as a great national hero. He was an independent genius who, although he was a foreigner, better than anyone reflected the Spanish Volksgeist of the time. In a period of social and political decline, he succeeded in reorienting Spanish art towards its native roots, while removing damaging foreign influences. While Raphael and his Spanish imitators used classic compositions and idealised figures, El Greco liberated himself from the stifling influence of Italian idealism and depicted reality as it was. He faithfully depicted Spanish society of his time by adopting the grey tones that were typical for Toledo and portraying ordinary Castilians 'dressed up as apostles'. This way, he developed a truly Spanish style and became the precursor of a glorious Spanish realism that culminated in the work of Velázquez and the Golden Age of Spanish art in the seventeenth century. Cossío even referred positively to El Greco's later, more extravagant works, which had been largely ignored until then, by calling them the result of his last 'impressionistic' phase. Although not all his experiments were 
successful, El Greco was a daring and original artist, who during the last stage of his career in fact anticipated many of the revolutionary innovations of the French Impressionists by more than two centuries (Cossío 1908).

Thus, like Justi, the Spanish scholar put much weight on the impact of the physical environment and historical traditions. In fact, according to Cossío, El Greco could not have chosen a better place than Toledo to get to know Spain's true nature. The city constituted a compilation of the various peoples and cultures that together had created Spanish civilisation, while its monuments formed a kind of museum where one could study the original features of Spanish art throughout its long history. Toledo was even a kind of recapitulation of the Spanish soil, landscape and nature, since it was built exactly where the barren Castilian plateau and Spain's rugged mountain ridges met. Since he was a brilliant artist, El Greco soaked himself in the purely Spanish atmosphere of Toledo in order to Hispanicise his painting style, but at the same time he succeeded in portraying his new fatherland as it truly was: a society in a state of beginning decay (Cossío 1908: 111-12 and 236-37). ${ }^{4}$ In a way, Cossío did not present El Greco only as an important and original painter, but he also presented him as a national hero, whose perseveration and creativity could function as an inspiring example for his compatriots.

This tendency was even stronger among the writers of the so-called Generation of 1898, such as Azorín, Pío Baroja and Miguel de Unamuno. Contrary to Cossío's rather conventional interpretation of El Greco as a realist painter, it can be argued that their more exalted nationalist view was home-grown. ${ }^{5}$ These relatively young authors presented El Greco during the first years of the twentieth century - so at the time when the established scholar Cossío was still preparing his biography - as a genius who did not so much depict the outer reality of Spanish society of his time, but penetrated into its innermost essence. They even preferred El Greco's highly spiritual paintings to the more mundane and realistic works of Velázquez. In November 1900, Azorín and Baroja made a pilgrimage to Toledo to see El Greco's masterpieces in their original setting. In novels such as Azorín's La voluntad (1902) and Baroja's Camino de perfección (1902), which both dealt with the difficult coming of age of a young intellectual, the fictionalised trip to Toledo functioned as a confrontation with the national past. However, they also published more journalistic articles and essays on El Greco's work in which they did not only regard it as a highlight of the past, but also as a guideline for the present. El Greco, maybe more than any other painter, embodied the national tradition, which also should be a starting point and source of inspiration for present-day artists. Without this solid ground, artists would be lost in a chaotic modern world in which everything seemed to have become relative and unstable (Storm 2011: 95-109 and 171-5). Although they were the first to interpret El Greco in this way, their view was heavily influenced by international intellectual developments of the time, such as a new emphasis on ideals and feelings, the pessimistic and nihilistic climate of the turn of the century and the rise of a new more exalted nationalism.

Moreover, the best known and most influential example of this new interpretation was produced in France. In 1911, the famous novelist Maurice Barrès published a short book titled Greco ou le secret de Tolède, in which he presented El Greco as a visionary painter who better than others had unravelled the collective psychology of Spain. According to him, the character of the Spaniards was not realistic and down to earth as Cossío had claimed, but profoundly catholic and spiritual. He therefore preferred the more exalted late altar pieces of El Greco, such as his Pentecost. This moving and swirling picture, with enormously elongated and exalted disciples gathered around the Virgin Mary, with flames above their heads that represented the reception of the Holy Ghost on Whitsun, had during the nineteenth century often been condemned as the work of a madman. For Barrès, however, this constituted a highly sensitive interpretation of an innermost Spanish religiosity, which according to him 
was still alive, especially in the old city of Toledo. Moreover, he also presented it as an example for his fellow Frenchmen. According to him, Spaniards were still faithful to their national spirit, whereas the decadent and materialistic French had lost contact with their own national traditions (Barrès 1994).

These authors also emphasised the interpenetration between El Greco and the local Volksgeist. While Justi and Cossío had emphasised the impact of Spain's high culture, the city's architectural monuments and the actions of the king and local ecclesiastical leaders, these representatives of a younger generation gave a more populist interpretation of the Spanish national character. Thus, Baroja wrote that the melancholic atmosphere that reigned in small Castilian towns such as Toledo and Illescas had a large impact on El Greco's mind, while Barrès argued that the mystic and ascetic religiosity that was particularly palpable in El Greco's late altar pieces was still alive among the common inhabitants of the city (Baroja 1900; Barrès 1994; 517-18). Notwithstanding these differences, since the late nineteenth century it had become a commonplace, both among Spanish and foreign authors, to identify El Greco with Toledo, while both were seen as characteristic of the Spanish Volksgeist.

\section{The local response}

In the meantime, local interest for El Greco was minimal. The Toledan Committee of Historical and Artistic Monuments limited itself primarily to supervising the architectural monuments of the city, while the local Church saw its artistic treasures primarily as objects of devotion (García Martín 2008; García Martín 2010) and as such El Greco's paintings were not highly appreciated. In 1913, for instance, a friar explained that El Greco's saints were skittish and gloomy, so believers did not dare to ask them for heavenly interception (Storm 2011: 38). Sextons, who showed visitors around the city's many religious establishments, seemed to repeat the early nineteenth-century legend that El Greco had become mad (Barrès 1994: 541). Even the local press initially ignored his rapidly growing fame. Thus, a small exhibition of El Greco's work that was mounted at the Prado Museum on the occasion of the accession to the throne of King Alfonso XIII in 1902 was not even mentioned in the Toledan newspapers. The same happened with a retrospective of his work at the vanguard Salon d'Automne in Paris in 1908, while the publication of the books by Cossío, Barrès and Meier-Graefe, which now unambiguously identified El Greco as Toledo's most emblematic artist and even as one of the greatest painters of all time, passed unnoticed.

When in 1906 and 1907 rumours about the sale of El Greco's paintings from various churches and chapels in Toledo led to extensive parliamentary debates, the local press remained silent or downplayed the issue (Storm 2013: 354-7). The catholic newspaper $E l$ Castellano even argued - with a clear reference to el desastre of 1898 - that judging from the commotion in the Cortes and the national press one would believe 'that Spain had been robbed of one of its richest and most fertile provinces' (El Castellano, 26 October 1907). ${ }^{6}$ Only the Republican weekly La Campana Gorda criticized the sale of El Greco's Saint Martin, to a Parisian art dealer. It argued that even if the painting and the Toledan chapel where it hung were the private property of the Count of Guendulain, the government should intervene to avoid that these objects of 'historical pride' were lost for Spain. However, even more than the loss of this work of art the author regretted the 'suicidal apathy' of the inhabitants, who remained indifferent and did not defend their local patrimony (Dananfer Infantes, La Campana Gorda, 17 and 24 October 1907).

At about the same time, the founding of the so-called House of El Greco by the Marquis de la Vega Inclán, an enterprising aristocrat from Madrid who had close contacts with Cossío and other progressive intellectuals, was met with suspicion, although this time it caused much debate in the local press. This seems more due to the susceptibility of the 
Toledans for being belittled by Madrid than to feelings of pride about El Greco's lasting contribution to Spain's artistic heritage. In 1905, Vega Inclán bought the remains of what presumably had been the house of El Greco. Two years later, he offered it to the state, with the aim of creating a small museum on the restored property (Menéndez Robles 2006). The Toledan press mentioned neither this donation, nor its acceptance by the conservative government. Two years later, however, the press was infuriated when a series of paintings by El Greco, which had been restored in the Prado Museum at the expense of Vega Inclán, were displayed at the Royal Academy of Arts in Madrid. Although it was clear that the paintings were destined for the House of El Greco, local journalists argued that they had been taken illegally from the Provincial Museum, and in fact belonged to city of Toledo. That the Provincial Museum had already been closed for years because of its ruinous state was not relevant. A few days later, an official delegation was formed in order to negotiate the question with the government in Madrid (Storm 2013: 357-9).

In June 1910, the issue seemed settled when King Alfonso XIII opened the new House of El Greco, which now showed the nineteen restored paintings of El Greco in a historicist setting that aimed to recreate the atmosphere of sixteenth century Castile. None of the local newspapers paid much attention to the opening of the museum or its exhibits, although the Marquis did his best to appease the local elites by inviting them to the museum days before the opening. On this occasion he told them that he hoped to convert the house into a museum of Castilian art and thus attract more tourists to the city, while he also announced his plans to celebrate the commemoration of El Greco's death in April 1614. With that goal in mind, in December 1912 a large committee was created, including representatives of both the local and national cultural elites. However, the rivalry between Toledo and Madrid again formed an unsurmountable obstacle. Only after the Marquis and his friends withdrew from the organisation, a few conventional and unpretentious activities could be organised, such as a small exhibition, a number of lectures, two concerts, a gala performance, two Masses and the unveiling of a classicist monument dedicated to the painter (Storm 2013: 359-61).

Nonetheless, the commemoration was an important turning point, since the conservative artistic establishment in Madrid finally embraced El Greco as a great Spanish painter. Already in 1910, the Prado's catalogue no longer categorised El Greco as a member of the Venetian school, but included him in the section of Spanish art (Hadjinicolaou 1990: 79). Traditional academic artists now also recognised El Greco as a great master, although they favoured his more realist early works. His later, more exalted paintings, which had become so popular among the rising avant-garde, were rejected as anomalous. Some even argued that these had been the product of a mental disorder or an eye disease. In April 1914, members of the Royal Academies of Art and History, which played a leading role during the commemoration, maintained that in his early realist masterpieces El Greco succeeded in conveying a very convincing picture of a time-honoured and profoundly Catholic society reigned judiciously by Philipp II (Storm 2011: 191-199).

Some local activists now also accepted El Greco as the city's artistic standard bearer because they understood the tourism possibilities of his newly acquired fame. Thus, the programme of the commemoration was translated into French, German and English, while the various Spanish railway companies offered a discount for those who wished to visit the city during the festivities (Centenario del Greco, 18 March and 4 April 1914). The idea that El Greco could be used to attract foreign visitors was even more obvious in the proposal of the conservative city councillor Manuel Cano to convert the city into a kind of open air museum, in which the inhabitants, together with members of the Spanish aristocracy, Jews and Arabs, would put on historical outfits to recreate the past. He even proposed to invite inhabitants of the Spanish protectorate in Morocco to give it an exotic twist. This way, Toledo could attract a large number of foreign visitors and become that year's most fashionable tourist destination 
(M. Cano Gutiérrez, El Eco Toledano, 9 and 15 January 1914). Because everyone was aware that this was not a feasible plan, it was ignored. This was not the case with Cano's proposal that the city take the initiative to organise a conference of Spanish Jews in Toledo (Storm 2013: 363-5). The Catholic press rejected Cano's proposal with force, arguing that the expulsion of the Jews - in 1492 - had been a wise decision. In a way, the journalists also understood that Cano's motives were mainly economical and by repeating old anti-Semitic stereotypes about the stinginess of the Jews they asserted that the plan would not reap positive results (El Castellano 21 March 1914; El Porvenir 19 March 1914).

In the end, a majority of the city's intellectual and political elites were convinced that it was a good idea to commemorate El Greco as one of the city's greatest artists. Only the Catholic right still preferred its own heroes - such as Saint Theresa - over this extravagant foreign painter. Evaluating the festivities in honour of El Greco after it had ended, the Catholic paper El Castellano argued that it had been a disappointing affair for lack of support among the people. It even admitted that: 'We are the first to be surprised that foreigners want to spend money to come [to Toledo] to see old paintings and historical ruins'. In order to solve this lack of appreciation for the artistic patrimony of the city, one had to improve the general cultural level of the population. Thus, it would have been better to have spent the money of the festivities in the funding of a new school. The reactionary Carlist El Porvenir even accused several conservative city councillors who actively defended El Greco's legacy of a lack of loyalty to the Church. Representatives of the left and of the mainstream political parties - the liberals and conservatives - meanwhile were suspicious of the Catholic clergy. Thus when in the wake of the commemoration the paintings of El Greco were removed from the altar of the monastery of Santo Domingo el Antiguo, many commentators fiercely criticised this decision, fearing that they would be sold as had happened with other of his Toledan masterpieces. It seemed that the prospect of the arrival of large numbers of foreign tourists made them more aware of the value of El Greco's art for the city.

Although the commemoration was not a great success, with conventional festivities, relatively few visitors, almost no national press coverage and heated local disputes, it still showed that El Greco had become an internationally recognised artist and that it could be worthwhile to exploit his memory in order to attract visitors. Since the opening of the House of El Greco the number of tourists had risen rapidly from about 1,000 a year to around 40,000 in 1913, and after a slump during the First World War it would exceed the 100,000 mark in 1925. The city did its best to accommodate the visitors and improve the tourist infrastructure, and it was clear that the sites where major works of El Greco could be admired were crucial (Camarasa 1927). In 1919, even the Church decided to show its artistic treasures in a special Cathedral Museum (García Martín 2008: 379). Thus, the association of El Greco and the city of Toledo in the eyes of foreign observers ultimately also made the inhabitants accept him as one of the main emblems of their city.

\section{Conclusion}

We may now conclude that foreigners largely determined the place of El Greco in the collective identity of Toledo. During the nineteenth century, mainly foreign scholars converted him into a national icon. They were the first to include El Greco in the story of Spanish art, the first to convert him into a Spanish painter, to give him a prominent role in the rise of a Spanish school, to appreciate the modernity of his painting style, to understand his art as a product of his new environment, to convert him into a symbol of Toledo and to regard him as one of the greatest interpreters of the Spanish 'soul'. These new, learned interpretations of El Greco as a quintessentially Spanish painter were quickly taken up by the Spanish cultural elites. However, until well into the twentieth century they received very 
limited acceptance among the local population. More influential for the diffusion of El Greco's fame as Toledo's artistic standard bearer was the rise of international tourism during the first decades of the twentieth century. The remarkable paintings of this awkward genius situated in mysterious churches, chapels and convents of a medieval city - became a precious asset, and the hard currency brought in by foreign visitors strongly enhanced El Greco's reputation among the local population.

However, one could argue that El Greco constitutes an exceptional case. He was an original painter who depicted the people and environment that surrounded him in a clearly recognisable style. As a result, El Greco was an artist perfectly suited to profit from the rise of nationalism. For those in search of national traditions it was quite logical to identify his art as Spanish. ${ }^{7}$ Maybe this was easier for foreigners, who only knew his Toledan paintings, than for Spaniards, who still regarded him as a Venice-educated Greek. However, this does not mean that the Spaniards were 'orientalised' and had no option but to accept a view imposed on them from the European core. In fact, Spanish authors applied the same nationalist template to the artistic past and in general arrived at similar conclusions.

Even if the foreign impact is not always as overwhelming as in this particular case, it should be admitted that collective identities are the result of a dialogue between local, national and foreign views. Even in countries of the European core - such as France, Great-Britain and Germany - transnational intellectual contacts were frequent and foreign views were taken into account. The rise of international tourism would only increase the impact of foreign preferences.

In order to avoid methodological nationalism while analysing the construction of collective identities, it is necessary to include both domestic and foreign actors. When we ignore these outside influences, we implicitly underscore the originality of domestic actors in selecting the unique features of their nation's collective identity, while in fact they adopted a transnational template that was already partially filled in by foreign observers. Moreover, the resulting identity also had to convince - and often attract - outsiders. If we now admit that national identities are not unique constructions determined by specific national circumstances, but the result of the application of a transnational model by both domestic and foreign actors, we should study it accordingly. 


\section{References}

Álvarez Junco, J. 2011 [2001]. Spanish Identity in the Age of Nations. Manchester: Manchester University Press.

Álvarez Lopera, J. 1987. De Ceán a Cossío. La fortuna crítica del Greco en el siglo XIX. Textos, documentos y bibliografía. Madrid: Fundación Universitaria Española.

Archilés, F. 2009. 'Narrar la nación fracasada. Narrativas del fracaso e historiografía española contemporánea' in: E. Nicolás and C. González (eds.), Mundos de ayer. Murcia: Universidad de Murcia, 217-48.

Augusteijn, J. and Storm, E. (eds.) 2012. Region and State in Nineteenth-Century Europe: NationBuilding, Regional Identities and Separatism. Basingstoke: Palgrave.

Baroja, P. 1900. 'Cuadros del Greco. Tierra castellana. En Santo Tomé', El Globo, 9 July 1900.

Barrès, M. 1994 [1911]. Greco ou le secret de Tolède in: Idem, Romans et voyages Paris: Bouquins, II. 511-64.

Baticle. J. and C. Marinas. 1981. La Galerie Espagnole de Louis-Philippe au Louvre. 1838-1848. Paris. Baycroft, T. and Hewitson, M. (eds.). 2006. What is a Nation? Europe 1789-1914. Oxford: Oxford University Press.

Bayly, C. 1998. Origins of Nationality in South Asia: Patriotism and Ethical Government in the Making of Modern India. Oxford: Oxford University Press.

Beller, M. and J. Leerssen (eds.) 2007. Imagology: The Cultural Construction and Literary Representation of National Characters: A Critical Survey. Amsterdam: Rodopi.

Berger, S. and C. Lorenz (eds.) 2010. Nationalizing the Past: Historians as Nation-Builders in Modern Europe. Basingstoke: Palgrave.

Blanc, C. (ed.) 1869. École Espagnole. Histoire des peintres de toutes les écoles VII. Paris: Renouard.

Boone, M. E. 2007. Vistas de España: American Views of Art and Life in Spain, 1860-1914. New Haven: Yale University Press.

Camarasa, S. 1927. 'Turismo', Boletín de la Real Academica de Bellas Artes y Ciencias Históricas de Toledo IX, 30: 3-28.

Chambers, E. 2010. Native Tours: The Anthropology of Travel and Tourism. Long Grove: Waveland Press.

Chatterjee. P. 1993. Nationalist Thought and the Colonial World: A Derivative Discourse. Minneapolis: University of Minnesota Press.

Cossío, M.B. 1985 [1886]. Aproximación a la pintura española. Madrid: Akal.

Cossío, M.B. 1908. El Greco. Madrid: Victoriano Suárez.

Fontbona. F. 1996. 'La recuperació d'El Greco per part dels modernistes catalans' in: J. Milicua (ed.), El Greco. La seva revaloració pel modernisme català. Barcelona.

García Felguera, M.S. 1991 Viajeros, eruditos y artistas. Los europeos ante la pintura española del Siglo de Oro. Madrid.

García Martín, F. 2008. Gestión del patrimonio catedralicio (1836-1931). Toledo: Ledoria.

García Martín, F. 2010. La comisión de monumentos de Toledo (1875-1931). Toledo: Ledoria.

Greenfeld, L. 1992. Nationalism: Five Roads to Modernity. Cambridge: Harvard University Press.

Hadjinicolaou, N. 1990. 'Domenicos Theotocopoulos 450 Years Later' in: El Greco of Crete (Iraklion: Municipality of Iraklion) 57-111.

Hewitson, M. 2006. 'Conclusion' in: T. Baycroft and M. Hewitson (eds.), What is a Nation? Europe 1789-1914. Oxford: Oxford University Press, 312-55.

Hroch, M. 1985 [1969]. Social Preconditions for National Revival in Europe: A Comparative Analysis of the Social Composition of Patriotic Groups among the Smaller European Nations. Cambridge: Cambridge University Press.

Jeismann, M. 1992. Das Vaterland der Feinde. Studien zum nationalen Feindbegriff und Selbstverständnis in Deutschland und Frankreich 1892-1918. Stuttgart. Klett-Cotta. 
Justi, C. 1888. Diego Velazquez und sein Jahrhundert. Bonn.

Justi, C. 1908 [1897], 'Der Greco in Toledo' in: Idem, Miscellaneen aus drei Jahrhunderten spanischen Kunstlebens. Berlin: G. Grote, II, 219-243.

Leerssen, J. 2006a. National Thought in Europe: A Cultural History Amsterdam: Amsterdam University Press.

Leerssen, J. 2006b., 'Nationalism and the Cultivation of Culture', Nations and Nationalism. 559-578.

Lefort, P. 1869. 'Domenico Theotocopuli, surnommé le Greco' in: C. Blanc (ed.) École Espagnole. Histoire des peintres de toutes les écoles VII. Paris: Renouard.

Luxenberg. A. 2008. The Galerie Espagnole and the Museo Nacional 1835-1853: Saving Spanish Art, or the Politics of Patrimony. Aldershot: Ashgate.

Manela. E. 2007. The Wilsonian Moment: Self-Determination and the International Origins of Anticolonial Nationalism. Oxford: Oxford University Press.

Mar-Molinero, C., A. Smith (eds.) 1996. Nationalism and the Nation in the Iberian Peninsula: Competing and Conflicting Identities. Oxford: Berg.

Martínez Gil. F. 2007. La invención de Toledo. Imágenes históricas de una identidad urbana. Ciudad Real: Almud.

Meier-Graefe. J. 1910. Spanische Reise. Berlin.

Méndez Rodríguez, L., R. Plaza Orellana and A. Zoido Naranjo. 2010. Viaje a un Oriente europeo. Patrimonio y turismo en Andalucía (1800-1929). Sevilla: Centro de Estudios Andaluces.

Menéndez Robles. M.L. 2006. El marqués de la Vega Inclán y los orígenes del turismo en España. Madrid: Ministerio de Industria, Energía y Turismo.

Molina, F. and M. Cabo Villaverde. 2012. 'An Inconvenient Nation: Nation-Building and National Identity in Modern Spain. The Historiographical Debate' in: M. Van Ginderachter and M. Beyen (eds.), Nationhood from Below: Europe in the Long Nineteenth Century. Basingstoke: Palgrave Macmillan, 47-73.

Morales Moya, A., J.P. Fusi Aizpurúa and A. de Blas Guerrero (eds.). 2013. Historia de la nación y del nacionalismo español. Barcelona: Galaxia Gutenberg.

Moreno Luzón, J. (ed.). 2007. Construir España. Nacionalismo español y procesos de nacionalización. Madrid: Centro de Estudios Políticos y Constitucionales.

Moreno Luzón, J. and X.M. Núñez Seixas (eds.) 2013. Ser españoles. Imaginarios nacionalistas en el siglo $X X$. Barcelona: RBA.

Murdock, C.E. 2010. Changing Places: Society, Culture, and Territory in the Saxon-Bohemian Borderlands, 1870-1946. Ann Arbor: University of Michigan Press.

Núñez, X. M. 2010. 'Nations andNationalism in Europe: Transnational Reflections', European History Quarterly 40: 669-84.

Özkirimli, U. 2000. Theories of Nationalism: A Critical Introduction. Basingstoke: Palgrave.

Portus. J. 2012. El concepto de Pintura Española. Historia de un problema. Madrid: Verbum.

Said, E. 1978. Orientalism. New York: Pantheon.

San Román, F.B. 1910. El Greco en Toledo o nuevas investigaciones acerca de la vida y obras de Dominico Theotokópuli. Madrid: Suarez.

Schroeder, V. 1998. El Greco im frühen deutschen Expressionismus. Von der Kunstgeschichte als Stilgeschichte zur Kunstgeschichte als Geistesgeschichte. Frankfurt am Main.

Smith, V.L. and M. Brent, M. (eds.) 2001. Hosts and Guests Revisited: Tourism Issues of the $21^{\text {st }}$ Century. New York: Cognizant Communication Corporation.

Stirling-Maxwell, W. 1891 [1848]. Annals of the Artists of Spain. London.

Storm, E. 2008. 'Julius Meier-Graefe, El Greco and the Rise of Modern Art', Mitteilungen der Carl Justi-Vereinigung 20: 113-33.

Storm, E. 2010. The Culture of Regionalism: Art, Architecture and International Exhibitions in France, Germany and Spain, 1890-1939. Manchester: Manchester University Press. 
Storm, E. 2011 [2006]. El descubrimiento del Greco. Nacionalismo y arte moderno (1860-1914). Madrid: CEEH and Marcial Pons.

Storm, E. 2013, 'Patrimonio local, turismo e identidad nacional en una ciudad de provincias: Toledo a principios del siglo XX', Hispania 73, 224: 319-48.

Storm, E. 2014, 'Overcoming Methodological Nationalism in Nationalism Studies: The Impact of Tourism on the Construction and Diffusion of National and Regional Identities', History Compass 12, 4: 261-73.

Tacke, C. 1995. Denkmal im sozialen Raum. Nationale Symbole in Deutschland und Frankreich im 19. Jahrhundert. Göttingen: Vandenhoeck \& Ruprecht.

Tacke, C. 1998. 'National Symbols in France and Germany in the Nineteenth Century' in: H.G. Haupt, M. Müller and S. Woolf (eds.) Regional and National Identities in Europe in the XIXth and XXth Centuries. The Hague: Kluwer, 411-436.

Thiesse, A.-M. 1999. La création des identités nationales. Europe XVIIIe-XXe siècle. Paris: Seuil.

Torrecilla, J. 2004. España exótica. La formación de la imagen española moderna. Boulder: University of Colorado.

Van Ginderachter, M. and M. Beyen (eds.) 2012. Nationhood from Below: Europe in the Long Nineteenth Century. Basingstoke: Palgrave Macmillan.

Vickers, B. 1989. Bali: A Paradise Created. Berkeley: Periplus.

Wimmer, A. and N. Glick Schiller. 2002 'Methodological Nationalism and the Study of Migration', European Journal of Sociology 217-240.

Wismer, B. and M. Scholz-Hänsel (ed.) 2012. El Greco and Modernism (Ostfildern: Hatje Cantz). Zacharasiewicz, W. 2010. Imagology revisited. Amsterdam: Rodopi.

\footnotetext{
${ }^{1}$ This article is the product of a larger research project 'La nación desde la raíz. Nacionalismo español y sociedad civil en el siglo XX' funded by the Spanish Ministry of Economy and Competitiveness (HAR2012-37963-C02-01).

${ }^{2}$ As another sign of the dominant role of methodological nationalism, Javier Portús' book on the 'construction' of the Spanish School only discusses the contribution of Spanish authors. Foreigners, such as Stirling, Blanc and Justi are mentioned, but have no agency.

${ }^{3}$ Both painters came from the Spanish periphery, Rusiñol being a Catalan from Barcelona, while Zuloaga originated from a noted family of artisans from the Basque Country.

${ }^{4}$ Cossío actually seemed to paraphrase a large passage in which Justi described the cultural and political decline of Spain towards the end of the seventeenth century. Compare Justi 1908: II, 223-24 with Cossío 1908: 112-13.

${ }^{5}$ The term Generation of 1898 is another example of methodological nationalism, since it suggests that this literary generation primarily reacted to the disastrous defeat of Spain in the Spanish-American War of 1898, whereas they clearly were a product of the international Fin-de-Siècle climate. Often the painter Ignacio Zuloaga is also included or at least associated with this group.

${ }^{6}$ The exception to this rule was the young, local scholar Francisco de Borja San Román, who dug up 88 unknown archival documents concerning El Greco (San Román 1910).

${ }^{7}$ The story more or less repeated itself in Greece, where the interest in the art of this famous lost son rapidly increased after the First World War (Hadjinicolou 1990).
} 